\title{
Sociosemiotic perspectives on studying culture and society
}

\author{
Anti Randviir \\ Department of Semiotics, University of Tartu, \\ Tiigi 78, 50410 Tartu, Estonia \\ e-mail: randviir@ut.ee
}

\begin{abstract}
The article analyses the position of sociosemiotics in the paradigm of contemporary semiotics. Principles of studying sociocultural phenomena are discussed so as they have been set for analysing the inner mechanisms of sign systems in the semiology of F. de Saussure on the one hand, and for studying sign systems and semiotic units as related to referential reality in the semiotics of C. S. Peirce on the other hand. Three main issues are touched upon to define the scope of sociosemiotics: the general methodology of sociosemiotics, its particular methods, and possible objects of analysis. The relevance of the features of objects in different humanitarian disciplines (cultural unit, historical fact, social fact, institutional fact, social process, etc.) is surveyed to define the object of study in sociosemiotics. Also, the article comments on the description of social organisations via cultural processes and on relations between an individual and society as controllable by social action models.
\end{abstract}

\section{Introduction: Semiotics and the logic of 'subsemiotic' disciplines}

It has become a commonplace to distinguish between different areas of semiotics by the objects of those fields. Notions like 'semiotics of literature', 'semiotics of advertising', 'semiotics of space', 'semiotics of music', etc. are often used according to such logic that as if presumes that all of a sudden a new range of objects has appeared, or, vice versa, sociosemiotics has as if arrived belatedly at the Great Delivery of Objects, and thus must find something new to study in order to justify its existence. It seems necessary to explicate why these 
possible understandings are incorrect and to propose ideas concerning rescuing the currently fuzzy discipline of sociosemiotics from its present vagueness. The solution will probably influence the unwritten principles of dividing the general semiotic field as well.

To begin with, we should not constrain ourselves with the mere distinction between Saussurean semiology and Peircean semiotics. Rather, their influence on the emergence of e.g. cultural semiotics, biosemiotics, etc. should be observed. As mentioned above, in the contemporary semiotic discourse it has become common to distinguish between different 'subsemiotic' disciplines according to the objects dealt with (e.g. the general situation in semiotics as currently concerned with to three main fields labeled as cultural semiotics, biosemiotics and sociosemiotics). The structure of these fields is organized according to a more subtle differentiation between research objects (e.g. in the general area of cultural semiotics we can find literary semiotics, semiotics of theatre, semiotics of advertising, cinema, etc.). There are virtually no limitations to the branching of semiotics in this manner and therefore we can even come across such terms as semiotics of traffic signs or refrigerator semiotics (see, e.g., Vihma 1995). However, this seems confusing, especially at a time when semiotics is becoming more and more institutionalized (e.g., wide variation in organization of chairs in departments, programs and curricula), which presupposes at least some common understanding of semiotics as a unified discipline that should be comparable to areas with a longer history of institutionalization that is manifested on a scale ranging from relevant text-books to organizations. Furthermore, the ad hoc labeling of 'subsemiotic' disciplines according to their objects does not seem to be grounded due to their intrinsic inseparable nature (e.g., it would hardly be fruitful to study semiotics of theatre, not paying attention to, for example, the latter's literary or artistic aspects). Unified understanding of the semiotic paradigm is thus essential already from the educational point of view.

Another way to create a division of the 'subsemiotic' branches of research would be to follow the logic of information channels (e.g., the optical channel; see Landwehr 1997, the acoustic channel; see Strube, Lazarus 1997, the tactile channel; see Heuer 1997, etc.). Also terms like 'visual semiotics', 'semiotics of space' and the like point at the possibility of differentiating between objects on the basis of the channels of human perception by which the world is turned into signs. However, it is doubtful that these channels can be actually studied separately (see, e.g., Krampen 1997). Also, different areas of semiosis 
have been articulated that lead to, and are included in, the cultural processes of anthroposemiosis: microsemiosis, mycosemiosis, phytosemiosis, zoosemiosis (see Wuketis 1997).

Sociosemiotics - a term relatively frequently used in contemporary semiotic discourse - is a recent development in semiotics. However, when we attempt to delimit its field, we meet a puzzling situation: there hardly exists either any clear-cut definition of the theoretical paradigm of sociosemiotics, or any outline of the range of its genuine objects. Amongst the very few existing definitions of sociosemiotics we can refer to the one by Alexandros Lagopoulos and Mark Gottdiener who state: "sociosemiotics is materialistic analysis of ideology in everyday life" (Gottdiener, Lagopoulos 1986: 14). This approach, however, seems to be both tautological as well as 'too materialistic'. Since in semiotic analysis we cannot escape from the everyday life and consummation of signs already at the stage of collecting data (see, e.g., Danesi, Perron 1999: 293ff), nor from the necessarily pragmatic angle of semiotic studies. Furthermore, it is apparent that all sign systems are inevitably ideological by nature and that this is revealed in our everyday behavior through the transformational rules guiding overt behavior.

Sociosemiotics is a topic often considered with caution and left undefined, although at the same time the term appears in the titles of numerous publications (e.g., Halliday 1978; Hodge, Kress 1988; Alter 1991; Flynn 1991; Riggins 1994a; Jensen 1995; etc.). Thus, if we use the notion at all, the first task to be completed is the clarification of the boundaries of sociosemiotics. To do this, the historical developments of the humanities are to be considered, especially as these converge, crisscross and diverge during the tense period at the turn of the 19th and 20th centuries. In this perspective special attention has to be paid to (cultural) anthropology, semiology and semiotics, early sociology and other social sciences. The next step would be examination of the contemporary state of semiotics and reasons for the activation of different 'subsemiotic trends' as related to the mentioned prevailing trends in semiotics, in order to distinguish the grounds for the (re)creation of a (new) field of sociosemiotics.

Jerzy Pelc (1997) approaches the topics listed above from a more general viewpoint, trying to vivisect semiotics from the larger to smaller parts. According to Pelc, there exist more general levels of semiotics, such as framework and metastructures, and applied semiotics that also includes the field of sociosemiotics (Pelc 1997: 636). Pelc's argument follows the ideas of Morris (1946) in that "the 
application of semiotics as an instrument may be called 'applied semiotic" and "applied semiotic utilizes knowledge about signs for the accomplishment of various purposes" (Pelc 1997: 636). Pelc mentions that:

one may also have in mind not only semiotic methods but also definitions and statements contained in theoretical semiotics which then becomes a common basis for various applied semiotics. (Pelc 1997: 636).

This again points at the impossibility of introducing different trends of applied semiotics without support from, and integration with, general theoretical semiotics. Likewise, there should always be a ground for creating the above-named subsemiotic disciplines. Thus, it may still be questionable to a degree, whether we can use the term 'applied semiotics' because of a necessary strong link with the theoretical aspect (otherwise, the applications obtain such an ad hoc nature that they start lacking common methods and principles). Hooking again up with Pelc's discourse:

each individual applied semiotics has its own theoretical foundations. And since some of the applied semiotics are humanistic disciplines (e.g. semiotics of theater), others are social (e.g. sociosemiotics), still others natural (e.g. zoosemiotics) or formal sciences (e.g. the study of deductive formalized systems), their theories too differ as regards methodology. (Pelc 1997: 636).

It seems, however, that Pelc's understanding of the general and the subsemiotic disciplines follows the realization of the need to pay attention to the intrinsically reflective nature of different semiotic trends with regard to the general semiotic paradigm. One must avoid distraction that may emerge if the sociosemiotic trend is considered as being theoretically "to a great extent characterized by features typical of theories in the social sciences" (Pelc 1997: 639). In addition to such a complementary aspect, it seems that it is exactly the theoretical connection with the general foundations of semiotics that should always be kept in mind. Other social sciences can offer the methodological aspects the principles of which are similar to those corresponding to old and basic semiotic presuppositions that have often been forgotten in actual studies (e.g. cultural semiotics and the pragmatic aspect of semiotics; see also Kavolis 1995: 8-9). So, if the realm of objects is, in the end, inseparable from the social realm due to their being semiotically conjoined and integrated, we may simply 
conclude that sociosemiotics should straightforwardly study all sociocultural phenomena. Such research should include the methods of all disciplines that allow the study of the different levels of sign production and exchange as presented by Bally and Sechehaye according to Ferdinand de Saussure. These levels include psychological, physiological and physical processes (Saussure 1959: 11-12), and link up both with Charles Peirce's discourse on logical and semiotic processes, as well as the above-mentioned areas and channels of semiosis. And regardless of difficulties in finding discussions of communication as a strict term in de Saussure's and Peirce's work, we can maintain that contemporary study of communication, together with different models and schemes of description, involves the above mentioned levels and processes of interaction in the same way as brought forward in sign creation and exchange. These aspects of communication also extend from the individual level up to general societal systems. The processual stages of sign exchange as communication have been more clearly articulated by Claude Shannon and Warren Weaver in their classical model of communication that is the source and basis for the majority of communication schemes today (Shannon, Weaver 1949). Other types of communication models center on the functions of interaction as presented by Roman Jakobson (Jakobson 1960).

\section{The scope of sociosemiotics}

It is impossible to overlook the fact that the terminology extensively used in several traditions of semiotics contains a considerable number of controversies. Even if we have posed studying of meaningful units and artifacts in sociocultural settings and communication chains of different types of integrated sign systems as the broad task of sociosemiotics, still the problem remains how to delimit both the units of study as well as the contexts of their emergence. Thus, an attempt should be made to find answers to three main sets of essential questions: (a) what are the principal starting points from which to find meanings and meaningful structures; (b) what are the methods of studying these meanings and meaningful structures; (c) what is or are the things to be studied.

In a way the last question has already been touched upon, when speaking in a broader perspective of how to distinguish between different objects of study. The methodological perspective concerns 


\section{Anti Randviir}

the question how to recognize semiotic, or rather sociosemiotic meaningfulness in the realms and units under inspection. In literature on semiotics we occasionally meet the term socialness. Among others a collection of articles edited by Steven H. Riggins (1994a) could be mentioned, that is based on the standpoint that "objects are a cause, a medium, and a consequence of social relationships" (Riggins 1994b: 1). Things, objects of common life are social in their essence, and, accordingly, there must be a criterion in semiotics that can be called socialness. It is interesting to note the similarity of such reasoning with Russian Formalism and the idea of turning attention to 'literariness' instead of 'literature'. A central characteristic in discovering the socialness of objects is interaction. Interaction is not restricted to communication between objects and people or the usage of objects in communication, but involves a considerably wider range of phenomena and aspects. Objects are often classified according to their pragmatic function and value of use, but they also serve as means of interaction between people. Objects are meaningful units and as such depend on their concrete communicative context and act of use. Objects may be involved in an individual's 'unilateral' communication with the social, cultural and physical environment, and they may be used for exchange of messages between several persons. However, from the point of view of semiotics, differentiating between the situations of object use in terms of unilateral communication and interaction of more than one individuals does not seem to be productive. The formation of the semiotic subjects as counterparts in communication and thus in interaction both with and by objects is always social, linking the individual to the societal, since objects have gained their 'starting-point meaning' due to sociocultural circumstances. For example, even when looking at furniture in private rooms or viewing intimate things that are special tokens for an individual person only or for a very limited group of individuals, we confront items that may be just ordinary commodities for the rest of the community, while the particularized meanings ascribed to them still derive from social experience, memories, cultural values or the similar. With the Saussurean term to describe distinct elements (and distinctiveness of elements) of a semiotic system in mind, value, indeed, derives from interaction with other elements of the system, and this interaction is activated and dynamically directed by the users of the system. This becomes obvious in such examples as symbols of the nation kept in a wallet, the national flag kept on the top of a desk at home, etc. Culture, cultural phenomena, human sign systems are 
indeed social in this sense; artifacts are social in their meaning (and dynamic in this meaning) by virtue of integrated use of all cultural semiotic systems. Socialness always derives from social interaction that leaves objects behind also as tokens of itself. Thus 'the socialness of things' may at first seem a trivial expression, but it serves to indicate that human beings have charged most artifacts with such a burden of cultural and individual history and meanings that it has become difficult to identify oneself without those objects. Therefore a description of the socialness of things should involve an analysis of the identity discourse of both individuals and larger sociocultural groups in various dimensions of the criteria possibly used for determination of social units (language, social order, artifacts, chronotope, ethnic structure, etc). The connection of artifacts and social structures in all possible types of communication further leads to the theme of identity, socialness and cultural fetishism in the widest sense that seems to be already an independent sociosemiotic theme.

An idea of the semiotic power of objects is widespread, one may recognise it in Karl Marx's notion of 'material communication of men' (derived from Freud), and often also in (cultural) anthropology - e.g. exchange systems of goods, tokens and commodities. (Some instances in cultural anthropology demonstrate also semiotically especially interesting cases of people, mostly women, being 'objectified' as units of communication in exchange systems.) Separation of such 'material communication' from Freud's communicationalsemiotic dimension of interaction seems too artificial, for artifacts are but one form of sign-vehicles. Artifacts are subject to social facts that, in Emile Durkheim's expression, are characterized as: "Every way of acting which is general throughout a given society, while at the same time existing in its own right independent of its individual manifestations" (Durkheim 1938: 13). It is a separate question where exactly those meaning-loaded realities external to the individual exist, and it has been discussed at length in that branch of cultural anthropology that looks upon cultures as symbolic systems. This trend is represented by, e.g., Clifford Geertz (Geertz 1973) and David Schneider (Schneider 1968), the main idea being that meanings do not exist in the 'heads of social actors', but 'in-between their heads'; i.e., meanings are not personal, but social. Considering Durkheim's social fact and semiological studies of approximately the same period, we can refer to a relevant comparison presented by Roy Harris (Harris 1991). Harris compares the notion of social fact to issues connected with Saussure's langage. A question may be posed as to the possible 
mutual influence of both authors on each other in terms of these two concepts. Langage and social fact may seem similar as they point at approximately same level of abstraction in comparison with the individual use of sign systems. However, it is to be borne in mind that according to Saussure language can be examined through parole, in the same way as the fundamental level of all sign systems can be reconstructed through case analyses of individual usage acts. Durkheim's social fact, on the other hand, cannot be ultimately clarified, because individual uses of social facts are, for him, far too imperfect to provide data regarding sociocultural superstructures. Harris claims that:

[...] there is no basic difference between the Durkheim of Les règles de la méthode sociologique and the Saussure of the Cours, granted the interpretation of Saussurean langage as something 'universal to the human nature' and of langue as a social production in the sense that every language presupposes a particular culture or community whose purposes it serves. Moreover, the implication is that for Durkheim such facts as are 'universal to human nature', even though they clearly affect people's social behavior, lie outside the scope of sociology (Harris 1991: 225-226).

However, for contemporary semiotics which is an interdisciplinary science in its perspectives on studying sociocultural phenomena, these differences need not be important any more and seem to have merged with new units of study. On the one hand, it has been proposed that the means and ends of cultural analysis are cultural units (Schneider), on the other hand, we can refer to historical facts (Uspenskij) that constitute sociocultural contexts and influence the functioning of semiotic systems in a constructed semiotic reality. Schneider defines cultural units in the following way:

A unit [...] is simply anything that is culturally defined and distinguished as an entity. It may be a person, place, thing, feeling, state of affairs, sense of foreboding, fantasy, hallucination, hope or idea. (Schneider, 1968: 2)

Therefore cultural units that exist in semiotic reality include both concrete and abstract reference and they need not necessarily be connected with referential realities. Cultural units are constructs that make up culture and have been created in a sociocultural system. Sociocultural contexts are not constructed only in terms of cultural objects and artifacts (Riggins 1994a), institutions (Berger, Luckmann 1972) and language (Halliday 1978, Searle 1995), but also as reflec- 
tive systems that continually make and remake their identity discourse in terms of historical facts (Uspenskij 1988). Historical facts represent the 'game between the present and the past' in which:

from the viewpoint of the present there is executed a choice and understanding of the past events - inasmuch as memory of them is preserved in collective consciousness. By this the past is organized as text readable from the perspective of the present. [...] Correspondingly reception of history turns into one of the main facts of the evolution of the 'language' of history, i.e. of that language in which communication is enacted in the historical process. (Uspenskij 1988: 73-74).

Umberto Eco seconds the anthropological view in a semiotic perspective by defining the cultural unit semiotically as a semantic unit inserted into a system (Eco 1976: 66-68). This implies the social nature of any semiotic study and any semiotic unit, inasmuch as there would be no objects of study for semiotics outside the sociocultural context of use of a cultural unit in a (semiotic) system. One could agree with John Searle in calling socioculturally meaningful units institutional facts in contrast to noninstitutional or brute facts in the sense that the first are "dependent on human agreement" and "require human institutions for their existence" (Searle 1995: 2). Maybe the Sapir-Whorf hypothesis of linguistic relativity would indicate low attention of Searle to segmentation of external contexts into meaningful segments. However, Searle dwells on such an argument himself and admits that "in order to state a brute fact we require the institution of language, but the fact stated needs to be distinguished from the statement of it" (Searle 1995: 2).

\section{Culture as a (socio)semiotic system}

If we do not want each study to end with the conclusion that knowledge of the conscruction of the sociocultural reality cannot be obtained from the disintegrated nature of the appearances of the integrated, yet ungraspable whole, we should accept the standpoint that through strict analysis of - preferrably reflective - outcome of sociocultural semiotic conceptions about the semiotic reality of a socium through different types of behavior, we can make inferences about the regularities of behavior and about the Weltanschauung, semiotic systems and the similar, of the given sociocultural group. 
When trying to define the content of culture for contemporary semiotic analysis, we cannot overlook the development of cultural anthropology during the 20th century. It is interesting to notice that European cultural anthropology has had such roots in early sociology and Saussurean semiology that are revealed in structural anthropology. Furthermore, principles of semiology, structuralism and formalism are evident in the parallel development of cultural semiotics. Semiology is important both as regards structural anthropology as well as cultural semiotics, being a factor directing such trends of culture studies toward analyzing sign systems as cognitive social systems. A gradual increase in emphasizing the description of cultural phenomena as an outcome of individually (or communally) articulated social sign systems essentially meant approaching those schools in cultural analysis that are associated with the cognitive trends in cultural anthropology. Those trends expose a steady movement from the late 19th century description of cultures as sets of artifacts organized according to cultural patterns toward the interpretation of cultures as ideational systems. This means that cultures were not 'made' any more only on the metalevel through organizing relations between cultural phenomena in scientific discourse. While cultures can be viewed as 'theories' in Kluckhohn's sense (Kluckhohn 1961) throughout the development of the humanities, an increased attention to them as abstractions existing already on the level of the cultural object has been characteristic of schools analyzing cultures as ideational or semiotic systems. Sociocultural systems are reflective systems and the overt behavior revealed in culture traits depends on the covert behavior directed by cognitive structures such as image schemata, values, behavioral schemes, etc. Thus, the aim of understanding cultures is to describe them as systems of knowledge, intersemiotic sign systems, reflective systems. To interpret the ideas of the cognitive anthropologist Ward H. Goodenough (see, e.g., Goodenough 1961, 1980, 1981), cultures are sets of decision standards, intellectual forms, perception models, models of relating, interpretation models, preference ratings and organizational patterns. For a unified cultural anthropology these cognitive structures converge into sociocultural systems that have been defined by Roger M. Keesing as systems that "represent the social realizations or enactments of ideational designsfor-living in particular environments" (Keesing 1974: 82).

If we take the object of sociosemiotics and semiotic study of culture in general to be sociocultural systems in the above-defined sense, we have established a broad principle according to which to 
understand the aim of analyzing similar systems. We have determined that artifacts and overt behavior are mediated by sign systems that have been built on the communal agreement behind which lie sociocultural values, socially constructed cultural tradition, etc. Logically, the next step would be to determine the units of concrete study; i.e., to select the 'adequate', the 'representative', 'valuable' sign systems that would enable us to reconstruct in a reliable way the semiotic reality of a social unit on the basis of data collected by observation. But before that the most crucial and painstaking task is to explicate the definition of a relevant social unit. When talking about 'cultural semiotics', 'sociosemiotics' or other subsemiotic trends, we by default assume analyzing sociocultural phenomena in a certain semiotic community. In cultural semiotics the rather useful term 'socium' has often been used to refer to a concrete community that can be described as a coherent unit in terms of social organization, location in time and space, distinct culture, and often an individual natural language. How to determine a sociocultural system is a most troublesome problem: which criteria are to considered as distinctive - language, culture, territory, social organization, nationality or some other possible category? It is a difficult task to find suitable definitions to each of them, but it is fairly obvious that all of them are in fact socioculturally constructed categories. Solutions can be wideranging, from analyzing cultural phenomena as texts representing cultural epochs defined in terms of coherence between cultural texts to actual determination of social groups. Social congregations can and have been distinguished in most general terms as social organizations coherent in membership sentiment that is due to shared visions of culture and cultural well-being. Ideal culture and cultural ideals have been considered as defining features in understanding society as a community whose members share the vision of Good Life (see, e.g., Redfield 1960) that also determines the perspective of norms as standardized mass habits of behavior according to the imagination of 'how things ought to be' (see Hoebel 1960). In spite of their essence seeming vague at first glance, it can still be maintained that sociocultural visions that influence everyday behavior form a basis on which the members of a sociocultural community can actually be quite exactly delimited and counted: according to Kluckhohn (1961), society refers to a group of people in which individuals interact with one another more than with other individuals; it consists of people who cooperate in order to achieve certain goals. 
Defining the aims of a social organization, we again come to the crossroads of cultural anthropology, psychology and semiotics: the dynamism between humans as biological organisms and humans as cultural beings is revealed in the tasks of the social organization. In terms of Jurgen Ruesch, "social organization is designed to achieve a designated purpose and to prevent conflict" (Ruesch 1972: 25). Ruesch maintains that:

The purpose of social organization is to: define group tasks; delineate boundaries in time and space (to each his own); establish priority systems (value systems); provide for emergencies (protective services); make new rules (legislature); interpret the rules (judiciary); reinforce the rules (law enforcement); allot positions within the organization (civil service); make decisions (executive); initiate and implement group action (exploration of outer space); and regulate exchange with other groups (competition, cooperation). (Ruesch 1972: 25-26)

The build-up and the relevant tasks of a social organization also reveals in general principles the latter's connection to the cultural processes that can be witnessed in both intra- and intercultural interaction. On the one hand it is clear that the social organization is structured to meet the various needs of an individual; on the other hand, it is obvious that an individual is connected to a certain social reality via socialization. The following question might concern the relation between the individual and a social organization in terms of their possible influence on the behavior of each other. How an individual can influence the social organization (s)he belongs to is quite a specific question already, and today we can more often speak about how a social organization communicates with its individual members. A further specific problem is added by the media that represents a third party in shaping the relationships between a social organization and its members. But first: a social organization can communicate and operate with its members by certain social actions. These engagements can be called social operation or action models (see e.g. Ruesch 1972: 401), and their features depend on how a given sociocultural system sees its social organization in terms of categories. In turn, success in guaranteeing the totality and coherence of a social organization depends on the explicit determination of the constituents of a society (e.g. native, labor, ethnic, linguistic, kinship or other elementary groups) and application of the relevant social operational action models. If operational models are applied to irrelevant societal categories or used in inadequate manner as regards the sociopsychological 
needs of an individual, they rather disintegrate the society than congregate one (see Figure 1). Individual sociopsychologial needs ought to be understood as dynamism between the needs of an individual (in A. Maslow's terms) and her/his understanding of his/her obligations to the social whole.

The connection between a social organization, its sign systems and individual variations in uses of semiotic tools offered by a sociocultural system can be studied, based on culture and its semiotic mechanisms. In other words, the coherence of a social organization can be measured by the integration of its members' cultural behavior. This is a topic originating already from Noam Chomsky's linguistic competence and leading to the current notion of semiotic competence; nevertheless, it indicates the structure of social organizations as based on cultural processes. Cultural processes that influence the structure of society and semiotic reality include, for example, acculturation, accommodation, integration, adjustment and integration with their several specific variations. Cultural processes may be influenced by social action models that finally determine cultural distances between different sociocultural groups. Cultural distance, in its turn, is measurable by comparing different features of both overt and covert behavior (see an example in Ruesch 1972: 186). These features are connected with the above discussed cultural units and institutional facts and sociocultural deep structures with and by which individuals operate with the various dimensions of environment. And inasmuch as such semiotic entities are revealed in the output of different semiotic systems, their analysis should focus on the specific instants of variability in the distinctive features by which concrete enunciations bring forward the possible meanings of semiotic entities, in order then to reach their conditionally middled meanings. It is then possible to describe the grounds for and norms of the formation of paradigmatic groupings of meaningful units as valid for individuals in a particular social, cultural, temporal, geographic, linguistic environment. The alike analytic operations concern the rules of possible syntagmatic combinations and is connected with both the extent and the boundaries of a particular semiosphere as linked with sign systems. Here we must keep in mind the principle of arbitrariness governing the relation of sign systems and (semiotic) reality that, however, is limited by a given sociocultural context; therefore this arbitrariness, as described by de Saussure, is restricted for individuals and their use of semiotic systems in concrete referential realities is socioculturally regulated. 
The idea of culture as an abstraction existing already on the object level, together with the principle of controllable data and analysis that would insure congruence between 'culture' as a metalevel theoretical construct and the understanding of semiotic phenomena by the users of a given semiotic community, points at another perspective in sociosemiotics. This perspective is concerned with the development of semiotic vocabulary and discourse in the reflective discourse of a given sociocultural group. This topic involves the usage of explicitly semiotic vocabulary in natural languages in everyday communication (see, e.g., Voigt 1998; Randviir et al. 1998), but also in the reflective output of culture. The latter aspect points at difficulties that often emerge when an attempt is made to draw a line between the scholarly viewpoint and the object level. Yet treatment of behavioral norms, culturally 'adequate' communication patterns, image schemata and the like is present in the majority of cultural texts, starting with myths, epics, lyrics, etc. Probably it would even be unfair to label some of such texts as 'scholarly pertinent', while letting others fall into the category of mere cultural phenomena. All reflective praxis is metacommunicative and thus, following E. Durkheim's logic, we can simply talk about different forms of reflective practices. Reflectivity is evident in religious practices, science, the institutional structure of a society, educational system, socialization process, instructions for the latter etc. Reflectivity is essential for the formation of social groupings and societies, inasmuch as it concerns the factor of sentiment binding individuals into a sociocultural system. In discussing formation of social organizations, we are to keep in mind several possibilities or criteria on the basis of which these can be founded: language, culture, statehood, territory, nationality, etc. All these categories are clearly conditional and follow Kluckhohn's logic of culture as an abstraction. Perhaps the only possibility to identify the membership of an individual is his/her subjective understanding as proposed by Ernest Gellner:

1. Two men are of the same nation if and only if they share the same culture, where culture in turn means a system of ideas and signs and associations and ways of behaving and communicating.

2. Two men are of the same nation if and only if they recognize each other as belonging to the same nation. In other words, nations maketh man; nations are the artifacts of men's convictions and loyalties and solidarities. (Gellner 1983: 7) 
Thus, on the one hand, people make up social organizations in order to support their identity discourse and satisfy their needs, and on the other hand social organizations ought to make up such a system that would provide individuals with tools to handle both infrastuctural, social and purely semiotic environments. Sociocultural organizations offer their members meaningful past and future visions, determining thereby also respected behavioral patterns for everyday interaction. Sociocultural organizations are by nature reflective organizations, both in respect to presenting sociocultural systems to other similar ones, and representing themselves in the course of formation of cultural traditions (as revealed, e.g., in education). The degree of reflectivity may increase and decrease, and this is often connected with some type of culture change. Cultural change, being a result of the situation of stark contrast between the existing cultural patterns and changed environmental (natural, technical, social, political, etc.) conditions, demands higher reflection upon the cultural core and mainstream in order to keep the identity discourse stable or to reestablish it according to an alternative principle (e.g., to replace the territorial or political principle for the national or linguistic one). However, this reflection must be again a social process in the sense of demanding close cooperation between different social groupings of a society. In the opposite case, national sentiment and social integration will decrease and society as a totality of subsystems will disintegrate (e.g., the case of several post-Soviet republics, including Estonia, in the new sociocultural and political world structure). The success of an identity discourse and cultural reflection as a social representation process depends on the clarity of understanding the structure of society in terms of partnership existing social organizations and groupings. This is the case concerning cultural change in the situation of overlapping boundaries in national, territorial and political terms.

The situation is different when we inspect the development of cultural or linguistic organizations of diaspora, as connected with the core cultures of both the new cultural space and the territory of origin. Such sensitive situation of cultural change also evokes the reflective praxises of immigrants and their intense search for identity. Emigration, especially forced emigration, amplifies the topic of acculturation and individual involvement in new sociocultural groups. Cultural and national identities obtain heightened importance, and it is representatives of such emigrants who often produce enunciations of understanding cultural and national identity. For example, a well-known Estonian cultural thinker Oskar Loorits has stated that it is most 
important to preserve 'Estonian behavior' and 'Estonian thinking' in diaspora, paying attention to the "national characteristics of Estonians', listing among them 'diligence or 'assiduity', durability or 'persistence' and 'tenacity', self-control or 'fortitude' and being content with little or "modesty", (Loorits 1953: 88). These gain especially great importance in comparison with the foreign others and awareness of them becomes more acute. Regarding the process of acculturation and national identity in diaspora, we can again refer to Loorits as a cultural critic disclosing features of Estonian-ness with his reference to the 'negative sides' of the Estonian national character that pale beside those of foreign communities:

in the character of foreigners (who have developed in much better conditions!) we can find much more egoistic stubborness and malicious glances, much more insidious spitefulness and more sly pulling legs, much more urging intriguing [...] (Loorits 1953: 88-89)

If cases are viewed in which its is the cultural or linguistic identity that is crucial for the identity of a social group, we can witness the very formation of European cultural, social and political landscape as based on the principle of nation states. According to E. Gellner's statement, "nationalism is primarily a political principle, which holds that the political and the national unit should be congruent" (Gellner 1983:1). However, like all possible criteria of defining social groups or communities, the sentiment determining membership feeling depends on social communication and is thus fundamentally connected with the ways in which available sign systems are used. Identies are constructed largely by the medium, and we can agree with Gellner in that:

The most important and persistent message is generated by the medium itself [...] That core message is that the language and the style of the transmissions is important, that only he who can understand them, or can acquire such comprehension, is included in a moral and economic community, and that he who does not and cannot, is excluded. (Gellner 1983: 127)

Thus all sociocultural communication, whether we inspect face-toface interaction, mass media, communication through objects or other media, is also metacommunicative and therefore provides sociosemiotic analysis of a community's semiotic reality with valuable information. Semiosis as a mediation process is social, and in fact it comprises syntactic, semantic and pragmatic analysis already on the 
object level. In this sense the object of social semiotics includes reflective practices that are social by virtue of cognitive processes and also because of the sign systems that can be used to articulate those processes. Thus, the field of sociosemiotics involves analysis of using culture and sign systems, and also sociosemiotic reflective thought through which bearers of a culture become aware of their sociocultural reality and sign systems. Sociosemiotics should treat the use of sign systems and meanings in sociocultural contexts, just as it should inspect the evolution of semiotic vocabulary and thought in society. This points at possibilities of control of descriptive discourse and the nature of sociosemiotic research as representing features of both general semiotics theoretically, and other social sciences in methodological perspective.

\section{References}

Alter, Jean 1991. A Sociosemiotic Theory of Theatre. Philadelphia: University of Pennsylvania Press.

Berger, Peter L.; Luckmann, Thomas 1972 [1966]. The Social Construction of Reality: A Treatise in the Sociology of Knowledge. Harmondsworth: Penguin Books.

Danesi, Marcel; Perron, Paul 1999. Analyzing Cultures: An Introduction and Handbook. Bloomington: Indiana University Press.

Durkheim, Émile 1938 [1895]. The Rules of Sociological Method. New York: Free Press.

Eco, Umberto 1976. A Theory of Semiotics. Bloomington: Indiana University Press.

Flynn, Pierce J. 1991. The Ethnomethodological Movement: Sociosemiotic Interpretations. (Approaches to Semiotics 95.) Berlin: Mouton de Gruyter.

Geertz, Clifford 1973. The Interpretation of Cultures: Selected Essays. New York: Basic Books.

Gellner, Ernest 1983. Nations and Nationalism. Oxford: Basil Blackwell.

Goodenough, Ward H. 1961. Comment on cultural evolution. Daedalos 90: 521528.

- 1980 [1970]. Description and Comparison in Cultural Anthropology. Cambridge: Cambridge University Press.

- 1981 [1971]. Culture, Language, and Society. Menlo Park: The Benjamin/ Cummings Publishing Company.

Gottdiener, Mark; Lagopoulos, Alexandros P. (eds.) 1986. The City and the Sign: An Introduction to Urban Semiotics. New York: Columbia University Press.

Halliday, Michael A. K. 1978. Language as Social Semiotic: The Social Interpretation of Language and Meaning. London: Edward Arnold. 


\section{Anti Randviir}

Harris, Roy 1991 [1987]. Reading Saussure: A Critical Commentary on the 'Cours de linguistique générale'. La Salle: Open Court.

Heuer, Herbert 1997. Der taktile Kanal. In: Posner, Roland; Robering, Klaus; Sebeok, Thomas A. (eds.), Semiotik: Ein Handbuch zu den zeichentheoretischen Grundlagen von Natur und Kultur. Vol. 1. Berlin: Walter De Gruyter, 300-306.

Hodge, Robert I. V.; Kress, Gunther 1988. Social Semiotics. Cambridge: Polity Press.

Hoebel, Edward A. 1960 [1956]. The nature of culture. In: Shapiro, Harry L. (ed.), Man, Culture, and Society. London: Oxford University Press, 168-181.

Jensen, Klaus Bruhn 1995. The Social Semiotics of Mass Communication. London: Sage.

Jakobson, Roman 1960. Closing statement: Linguistics and poetics. In: Sebeok, Thomas A. (ed.), Style in Language. Cambridge: MIT Press, 350-377.

Kavolis, Vytautas 1995. Civilization Analysis as a Sociology of Culture. Lewiston: The Edwin Mellen Press.

Keesing, Roger M. 1974. Theories of Culture. Annual Review of Anthropology 3: 73-97.

Kluckhohn, Clyde 1961. Mirror for Man: A Survey of Human Behavior and Social Attitudes. Greenwich: Fawcett.

Krampen, Martin 1997. Models of Semiosis. In: Posner, Roland; Robering, Klaus; Sebeok, Thomas A. (eds.), Semiotics: A Handbook on the Sign-Theoretic Foundations of Nature and Culture. Vol. 1. Berlin: Walter De Gruyter, 247288 .

Landwehr, Klaus 1997. Der optische Kanal. In: Posner, Roland; Robering, Klaus; Sebeok, Thomas A. (eds.), Semiotik: Ein Handbuch zu den zeichentheoretischen Grundlagen von Natur und Kultur. Vol. 1. Berlin: Walter De Gruyter, 288-294.

Loorits, Oskar 1953. Pagulaskodude kasvatusmuresid. Vadstena: Tõrvik.

Morris, Charles 1946. Signs, Language, and Behavior. New York: George Braziller, Inc.

Pelc, Jerzy 1997. Understanding, explanation, and action as problems of semiotics. In: Posner, Roland; Robering, Klaus; Sebeok, Thomas A. (eds.), Semiotics: A Handbook on the Sign-Theoretic Foundations of Nature and Culture. Vol. 1. Berlin: Walter De Gruyter, 617-667.

Randviir, Anti; Tarasti, Eero; Voigt, Vilmos 2000. Finno-Ugric semiotics: Cultures and metacultures. Sign Systems Studies 28: 425-438.

Redfield, Robert 1960 [1956]. How human society operates. In: Shapiro, Harry L. (ed.), Man, Culture, and Society. London: Oxford University Press, 345-371.

Riggins, Steven H. (ed.) 1994a. The Socialness of Things: Essays in the Sociosemiotics of Objects. (Approaches to Semiotics 115.) Berlin: Mouton de Gruyter.

- 1994b. Introduction. In: Riggins 1994a: 1-6.

Ruesch, Jurgen 1972. Semiotic Approaches to Human Relations. (Approaches to Semiotics 25.) The Hague: Mouton.

Saussure, Ferdinand de 1959. Course in General Linguistics. Bally, Charles; Sechehaye, Albert (eds.). New York: Philosophical Library. 
Searle, John R. 1995. The Construction of Social Reality. New York: The Free Press, Allen Lane.

Shannon, Claude E.; Weaver, Warren 1949. The Mathematical Theory of Communication. Urbana: The University of Illinois Press.

Schneider, David M. 1968. American Kinship: A Cultural Account. New York: Prentice-Hall.

Strube, Gerhard; Lazarus, Gerda 1997. Der akustische Kanal. In: Posner, Roland; Robering, Klaus; Sebeok, Thomas A. (eds.), Semiotik: Ein Handbuch zu den zeichentheoretischen Grundlagen von Natur und Kultur. Vol. 1. Berlin: Walter De Gruyter, 294-300.

Uspenskij, Boris A. 1988. Istorija i semiotika: Vosprijatie vremeni kak semioticheskaja problema. Sign Systems Studies (Trudy po znakovym sistemam) 22: 66-84.

Vihma, Susann 1995. Products as Representations: A Semiotic and Aesthetic Study of Design. Helsinki: The University of Art and Design.

Voigt, Vilmos 1998. A magyar jelek és jelrendszerek évszázadai. In: Voigt, Vilmos; Géza, Balázs (eds.), A Magyar Jelrendszerek Évszázadai. Budapest: Magyar Szemiotikai Társaság, 5-12.

Wuketis, Franz M. 1997. Anthroposemiose. In: Posner, Roland; Robering, Klaus; Sebeok, Thomas A. (eds.), Semiotik: Ein Handbuch zu den zeichentheoretischen Grundlagen von Natur und Kultur. Vol. 1. Berlin: Walter De Gruyter, 532-548.

\section{Социосемиотические перспективы при изучении культуры и общества}

Рассматриваются разделы семиотики и, соответственно, позиция социосемиотики в парадигме современной семиотики. Дается обзор принципов исследования социокультурных знаковых систем в том виде, как они даны, с одной стороны, в семиологии Ф. де Соссюра (анализ механизмов внутри знаковой системы) и, с другой стороны, в семиотике Ч. С. Пирса (изучение знаковых систем и знаковых единиц по отношению к означиваемой действительности). При определении предмета социосемиотики важны три главных вопроса: общая методология социосемиотики, ее методы и возможные конкретные объекты анализа. Прослеживаются признаки (единица культуры, социальность, исторический факт, социальный факт, институционный факт, социальный процесс и т.д.) возможных объектов разных наук о культуре с целью выяснения возможности их применения к определению объекта социосемиотики. Рассматривается и описание социальных организаций посредством культурных процессов и соотношений индивида и общества так, как эти соотношения можно регулировать социальными моделями действия. 


\section{Sotsiosemiootilised perspektiivid kultuuri ja ühiskonna uurimisel}

Artiklis vaadeldakse semiootika alajaotusi ja sotsiosemiootika vastavat positsiooni kaasaja semiootika paradigmas. Vaadeldakse sotsiokultuuriliste märgisüsteemide uurimise põhimõtteid nii, nagu need on sätestatud ühelt poolt märgisüsteemisiseste mehhanismide analüüsimiseks F. de Saussure'i semioloogias ning teiselt poolt C. S. Peirce'i semiootikas märgisüsteemide ja märgiliste üksuste uurimiseks suhestatuna viidatava reaalsusega. Käsitletakse kolme peamist küsimust sotsiosemiootika määratlemiseks: sotsiosemiootika üldine metodoloogia, meetodid ja võimalikud konkreetsed analüüsiobjektid. Jälgitakse eri kultuuriteaduste võimalike objektide tunnuste (kultuuriühik, sotsiaalsus, ajalooline fakt, sotsiaalne fakt, institutsiooniline fakt, sotsiaalne protsess jne) asjakohasust sotsiosemiootika objekti määratlemisel. Käsitlemist leiab ka sotsiaalsete organisatsioonide kirjeldamine kultuuriliste protsesside kaudu ning indiviidi ja ühiskonna seoste reguleeritavus sotsiaalsete tegelusmudelitega. 